\title{
Analysis of the Completeness of Procedures of Ventolin Inhaler Usage Through the Use of Video on Asthma Patients of Probolinggo Hospital
}

\author{
Godeliva Adriani Hendra*, Martanty Aditya, Chresiani Destianita Yoedistira
}

Pharmacy Study Program, Ma Chung University, Jl. Villa Puncak Tidar No 1, Malang, Indonesia, 65151

Correspondence: Godeliva Adriani Hendra (godeliva.adriani@machung.ac.id) Received: 26 November 2020 - Revised: 19 December 2020 - Accepted: 30 December 2020

\begin{abstract}
Asthma is an obstructive chronic pulmonary disease which causes shortness of breath and requires distinct diagnostic strategies and treatment management. The disease requires long-term treatment where the patient's condition can hopefully remain under control. There are still many symptom recurrences found in asthma patients due to inaccurate/incomplete procedures in using inhalers. The purpose of this community service is to develop knowledge and understanding of the completeness of usage procedures of Ventolin Inhalers by utilizing videos as visual training to achieve expected therapeutic effect and aid asthma patients in controlling/avoiding asthma relapse. Data collection was carried out through observation in the form of checklists which contained the procedures for using the inhaler, followed by descriptive analysis. The observations were made one month before and after video education. Education in video format was distributed on day one. The video was uploaded to Youtube and contain procedures on how to use the inhaler device. Alternatively, it can also be sent through the patient's WhatsApp account. The data collection process was carried out from April to July 2020. There were changes in the number of patients before and after the provision of video education. This shows the level of knowledge and understanding of asthma patients regarding the completeness of the procedure for using Ventolin Inhaler had increased. Inappropriate usage of inhalers or errors made during the implementation of each step can affect the effectiveness of drug therapy and can cause unwanted side effects.
\end{abstract}

Keywords: inhaler, video, asthma, usage technique, questioner

Citation Format: Hendra G.A., Aditya M., \& Yoedistira, C.D. (2021). Analysis of the Completeness of Procedures of Ventolin Inhaler Usage Through the Use of Video on Asthma Patients of Probolinggo Hospital. Journal of Community Practice and Social Welfare, 1(1), 23-32. 


\section{INTRODUCTION}

Asthma is an obstructive chronic pulmonary disease which causes shortness of breath and requires distinct diagnostic strategies and treatment management (Asthma, 2020). Asthma is known as an allergic disease. It usually appears in childhood and is characterized by hyperresponsiveness to the airway and is reversible. adversely, COPD is caused by smoking and characterized by progressive and irreversible airway obstruction (Kemenkes RI, 2012).

According to Riskesdas (2018), Asthma and COPD are among the NonCommunicable Diseases (NCD) category which occupy the top level of the nine largest NCDs in Indonesia with an incidence prevalence of $4.5 \%$ and $3.7 \%$ respectively (RI, 2018). Most of the treatments for both diseases are administered through inhalation, with a device known as an inhaler. Inhalers available in Indonesia consist of Metered Dose Inhaler (MDI), Dry Powder Inhaler (DPI), Soft Mist Inhaler (SMI), and nebulizers. Inhalers and nebulizers are types of pharmaceutical equipment whose technique of use can influence their therapeutic effectiveness. The advantage of using an inhaler is the effective delivery of drugs directly into the respiratory tract with little side effects (Lorensia \& Suryadinata, 2018).

A study evaluating the use of inhalers in patients with asthma and COPD in a primary health care facility showed that more than $80 \%$ of patients made errors in the usage of MDI or DPI and that the majority of asthma and COPD patients failed to use inhalers properly (Zazuli, Ramasamy, \& Adnyana, 2018). Another study in Korea regarding the expertise in using Turbuhaler, Discus, and Pressurized Metered-Dose Inhaler tools showed that instructions in the use of inhalers were not complete, leading to inappropriate usage (Lee et al., 2011). Each inhaler has advantages and disadvantages. The success of a treatment depends not only on the formulation of the drug but also on the patient's ability to utilize the equipment properly.

This requires information on how to use the inhaler appropriately to achieve an adequate therapeutic effect. This service (community service) works together with Probolinggo Regional Hospital, where the targets are asthma patients in the outpatient pharmacy department of the pulmonary polyclinic. The purpose of this service is to expand the knowledge on the completeness of usage procedures of inhalers by utilizing videos as visual training to achieve expected therapeutic effectiveness and aid asthma patients in controlling/avoiding asthma relapse. 


\section{PROBLEMS}

Based on this background, there are several problems faced by patients when buying drugs at pharmacies, namely the limited medium of information provided by pharmacists in understanding how to use inhalers. Initial interviews before carrying out the community service found that patients were given IEC (Communication, Information and Education) without using any media platforms such as leaflets, brochures, or videos. In addition, the lack of knowledge of pharmaceutical service providers regarding how to use inhalers has led to many errors in its usage by patients. Inhalers were only delivered by doctors briefly without the use of any media to explain the procedure. Public knowledge regarding drug information supports rational treatment and can spare patients from medication errors (Pratiwi, Nuryanti, Fera, Warsinah, \& Sholihat, 2016).

\section{IMPLEMENTATION METHOD}

The method used to solve this problem is the community education method. This method was implemented by providing a video showing the steps on how to use inhaler devices. The inhaler used was a $100 \mathrm{mcg} 200$ dose of Ventolin Inhaler (MDI). The video can be watched at home by sending it via the patient's WhatsApp account or as a researcher YouTube link. It is hoped that the video can be played back anywhere and at any time. Before distributing the educational video, the patients were given a questionnaire. The questionnaire was in the form of a checklist of stages/steps for how to use the inhaler and a table in the far-right side of the questionnaire was reserved for scores that the researcher can fill in (Table 1). The questionnaire contains 7 stages with 11 steps.

The data collection process was carried out on outpatients of the pharmaceutical department of RSUD Probolinggo from April to July 2020. The patients filled out questionnaires in the presence of researcher and pharmacist. Following this, patients were educated using videos relating to the techniques of using the aforementioned inhaler device. The patients were monitored for one month and they would then fill out the questionnaire again a second time. Subject selection was done through purposive sampling technique where researcher determine the sampling based on the selected type of inhaler device to be able to solve the community service problem. 


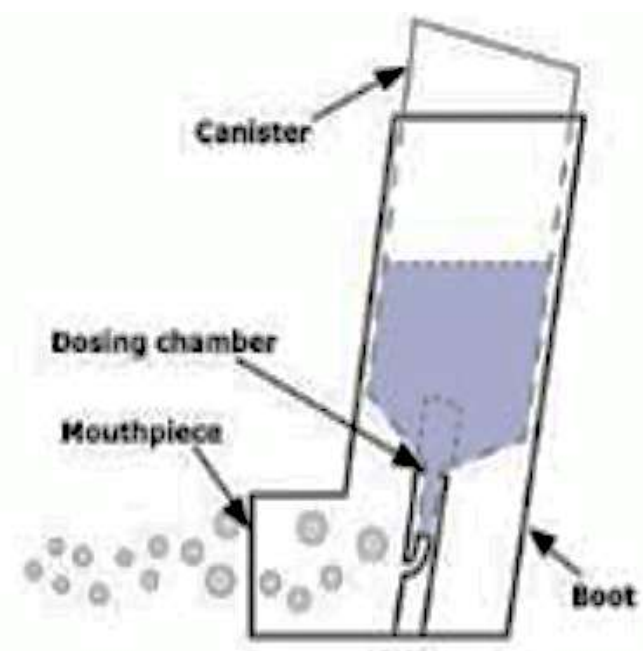

Figure 1. MDI composition (Metered Dose Inhaler) (June, Kadu, Kendre, \& Gursal, 2016)

The picture above describes the composition of MDIs, one of which is the Ventolin Inhaler. The canister is a container that accommodates the drug suspension solution. The dosing chamber contains drug-propellant. The MDI propellant is designed to condensate drugs from a gas into a liquid state when pressure is applied to the canister. The mouthpiece directs the flow of aerosol droplets through the oral cavity and into the lungs. The mouthpiece has a cover to keep it clean and is removed when in use (Lorensia \& Suryadinata, 2018).

Table 1. Usage procedure of Ventolin Inhalers without spacers (Lorensia, Queljoe, \& Valensia, 2018; Lorensia \& Suryadinata, 2018)

\begin{tabular}{|c|c|c|}
\hline No & Steps & Sub-Steps \\
\hline \multirow[t]{2}{*}{1.} & \multirow[t]{2}{*}{ Shake and open MDI cover } & $\begin{array}{l}\text { Shake the MDI 3-4 times vertically (critical } \\
\text { step) }\end{array}$ \\
\hline & & Open the MDI cover/cap \\
\hline \multirow{2}{*}{2.} & \multirow{2}{*}{ Hold MDI in an upright position } & MDI held in an upright position (critical step) \\
\hline & & Head held at an upright position (critical step) \\
\hline \multirow[b]{2}{*}{3.} & \multirow[b]{2}{*}{ Exhale as hard as possible } & Exhale normally \\
\hline & & $\begin{array}{l}\text { Exhale as hard as possible until unable to } \\
\text { release more air (critical step) }\end{array}$ \\
\hline \multirow[t]{2}{*}{4.} & \multirow[t]{2}{*}{ Place the mouthpiece in the mouth } & $\begin{array}{l}\text { Inhaler is held at an upright position between } \\
\text { the index finger and the thumb and about } 4 \mathrm{~cm} \\
\text { away from the lips (about } 2 \text { fingers) (critical } \\
\text { step) }\end{array}$ \\
\hline & & $\begin{array}{l}\text { Mouth at a wide-open state and the mouthpiece } \\
\text { placed between the teeth and lips (critical step) }\end{array}$ \\
\hline 5. & $\begin{array}{l}\text { Inhale and apply pressure to the } \\
\text { canister simultaneously, breathe again } \\
\text { afterwards }\end{array}$ & $\begin{array}{l}\text { Inhale air as much as possible and carefully } \\
\text { apply pressure to the top of the canister (do } \\
\text { this simultaneously) (critical step) }\end{array}$ \\
\hline
\end{tabular}


Table 1. Usage procedure of Ventolin Inhalers without spacers (cont)

\begin{tabular}{|c|c|c|}
\hline No & Steps & Sub-steps \\
\hline 6. & Hold breath, then exhale slowly & $\begin{array}{l}\text { Hold breath for } 10 \text { seconds, if incapable of this } \\
\text { step then the patient can hold his/her breath for } \\
4 \text { seconds, and then exhale slowly (critical } \\
\text { step) }\end{array}$ \\
\hline 7. & $\begin{array}{l}\text { Repeat steps } 2-7 \text { for the next dosage if } \\
\text { needed. }\end{array}$ & $\begin{array}{l}\text { If a second dose is needed, then patient must } \\
\text { wait for } 20-30 \text { seconds before repeating steps } \\
2-7 \text { (critical step) }\end{array}$ \\
\hline
\end{tabular}

The table above shows the procedures of using the Ventolin Inhaler without spacers, which were demonstrated by Ma Chung University students. The procedure for Ventolin Inhaler application is then recorded in video form. The video content was previously validated by the Ma Chung University lecturer team. In addition to providing education through the video, researcher also directly demonstrated the procedures to elderly patients.

\section{RESULTS AND DISCUSSION}

In total, there were 62 people categorised as asthma patients in the outpatient pharmacy department of District General Hospital Probolinggo from April to July 2020. The criteria for subject selection were asthma patients who participated in and completed the community education activities and users of Ventolin Inhalers. The number of community service samples was 31 patients.

Table 2. Descriptive results of Ventolin Inhalers procedure completeness in asthma patients

\begin{tabular}{|c|c|c|c|c|c|c|}
\hline \multirow{3}{*}{ No } & \multirow{3}{*}{ Steps } & \multirow{3}{*}{ Sub-Steps } & \multicolumn{4}{|c|}{$\begin{array}{l}\text { Asthma Patient } \\
(\mathrm{n}=31)\end{array}$} \\
\hline & & & \multicolumn{2}{|c|}{ Pre-test } & \multicolumn{2}{|c|}{ Post-test } \\
\hline & & & Amount & $\%$ & $\begin{array}{l}\mathrm{A} \\
\text { mount }\end{array}$ & $\%$ \\
\hline \multirow[t]{2}{*}{1.} & \multirow{2}{*}{$\begin{array}{l}\text { Shake and open the MDI } \\
\text { cover }\end{array}$} & $\begin{array}{l}\text { Shake the MDI 3-4 } \\
\text { times vertically } \\
\text { (critical step) }\end{array}$ & 2 & $6,45 \%$ & 22 & $70,97 \%$ \\
\hline & & $\begin{array}{l}\text { Open the MDI } \\
\text { cover/cap }\end{array}$ & 1 & $3,23 \%$ & 25 & $80,65 \%$ \\
\hline 2. & $\begin{array}{l}\text { Hold MDI in an upright } \\
\text { position }\end{array}$ & $\begin{array}{l}\text { MDI is held in an } \\
\text { upright position } \\
\text { (critical step) }\end{array}$ & 22 & $6,45 \%$ & 31 & $100 \%$ \\
\hline
\end{tabular}


Table 2. Descriptive results of Ventolin Inhalers procedure completeness in asthma patients (cont)

\begin{tabular}{|c|c|c|c|c|c|c|}
\hline \multirow{3}{*}{ No } & \multirow{3}{*}{ Steps } & \multirow{3}{*}{ Sub-Steps } & \multicolumn{4}{|c|}{$\begin{array}{l}\text { Asthma Patient } \\
(\mathrm{n}=31)\end{array}$} \\
\hline & & & \multicolumn{2}{|c|}{ Pre-test } & \multicolumn{2}{|c|}{ Post-test } \\
\hline & & & Amount & $\%$ & $\begin{array}{c}\mathrm{A} \\
\text { mount }\end{array}$ & $\%$ \\
\hline & & $\begin{array}{l}\text { The head is in an } \\
\text { upright position } \\
\text { (critical step) }\end{array}$ & 1 & $3,23 \%$ & 31 & $100 \%$ \\
\hline & & Exhale normaly & 1 & $3,23 \%$ & 29 & $93,55 \%$ \\
\hline 3. & $\begin{array}{c}\text { Exhale as hard as } \\
\text { possible }\end{array}$ & $\begin{array}{l}\text { Exhale as hard as } \\
\text { possible until unable } \\
\text { to release more air } \\
\text { (critical step) }\end{array}$ & 0 & 0 & 18 & $58,06 \%$ \\
\hline \multirow[t]{2}{*}{4} & \multirow[t]{2}{*}{$\begin{array}{l}\text { Place the mouthpiece in } \\
\text { the mouth }\end{array}$} & $\begin{array}{l}\text { Inhaler is held at an } \\
\text { upright position } \\
\text { between the index } \\
\text { finger and the thumb } \\
\text { and about } 4 \mathrm{~cm} \text { away } \\
\text { from the lips (about } 2 \\
\text { fingers) (critical step) }\end{array}$ & 0 & 0 & 17 & $54,84 \%$ \\
\hline & & $\begin{array}{l}\text { Mouth at a wide-open } \\
\text { state and the } \\
\text { mouthpiece placed } \\
\text { between the teeth and } \\
\text { lips (critical step }\end{array}$ & 0 & 0 & 24 & $77,42 \%$ \\
\hline 5. & $\begin{array}{l}\text { Inhale and apply pressure } \\
\text { to the canister } \\
\text { simultaneously, breathe } \\
\text { again afterwards }\end{array}$ & $\begin{array}{l}\text { Inhale air as much as } \\
\text { possible and carefully } \\
\text { apply pressure to the } \\
\text { top of the canister (do } \\
\text { this simultaneously) } \\
\text { (critical step) }\end{array}$ & 1 & $3,23 \%$ & 19 & $61,29 \%$ \\
\hline 6. & $\begin{array}{l}\text { Hold breath, then exhale } \\
\text { slowly }\end{array}$ & $\begin{array}{l}\text { Hold breath for } 10 \\
\text { seconds, if incapable } \\
\text { of this step then the } \\
\text { patient can hold } \\
\text { his/her breath for } 4 \\
\text { seconds, and then } \\
\text { exhale slowly (critical } \\
\text { step) }\end{array}$ & 5 & $16,13 \%$ & 30 & $96,77 \%$ \\
\hline 7. & $\begin{array}{l}\text { Repeat steps } 2-7 \text { for the } \\
\text { next dosage if needed. }\end{array}$ & $\begin{array}{l}\text { If a second dose is } \\
\text { needed, then patient } \\
\text { must wait for } 20-30 \\
\text { seconds before } \\
\text { repeating steps } 2-7 \\
\text { (critical step) }\end{array}$ & 0 & 0 & 31 & $100 \%$ \\
\hline
\end{tabular}

In Table 2, before the distribution of educational video, only two patients shook the Ventolin Inhaler correctly, some patients incorrectly shook the inhaler in a tilted position 
instead of vertically. Many patients did not shake before use and only one patient correctly explained that the MDI mouthpiece cover needs to be removed before shaking. After being educated, most asthma patients would follow the procedure correctly with a few cases of elderly patients forgetting the steps. Shaking before use (newly purchased Ventolin Inhaler) / after one week of no use is required to prevent a $33 \%$ reduction of the original dosage and avoid the release of non-uniform drug particles into the breathing tract. If it is not shaken or shook in a wrong angle, large particles can deposit on the inside of the mouth which risks the development of oral candidiasis. The drug particles are preferably deposited on the bronchioles with a particle size of $<5 \mu \mathrm{m}$ (Usmani, 2019).

Before education, most patients did not hold their MDIs in an upright position. The MDIs position, when held, can affect the dosage that enters the lungs. The drug container must be positioned at a higher elevation than the inhaler's outlet to achieve the expected therapeutic effect (Lorensia \& Suryadinata, 2018; Usmani, 2019). Only one patient exhaled Normally before the distribution of the video. Normal exhale is a necessary step in preparation for a deep breath. It can influence how effectively the drug will deposit in the lungs. However, forcible exhale/forced expiration is not recommended due to the risk of developing bronchospasms (Lee et al., 2011). After education, only 18 patients correctly performed firm exhalations while most exhaled normally.

Before education, the ways patients held and put the inhaler in their mouths were not optimal. The Ventolin inhalers used by the patients are a type of CFC which requires an open mouth technique. This type of device produces aerosols at high speed $(150 \mathrm{~km} /$ h), which results in sizable particle deposits in the upper airway tract. The proper method of use would be for the patients to open their mouths and place the mouthpiece between their teeth and lips. However, the patient would then keep their mouths closed.

Before education, patients would often not coordinate the act of pressing the canister and inhaling the drug by mouth/inspiration. This causes the drug to accumulate in the mouth with little to none of it depositing in the lungs (Asthma, 2020). After applying pressure to the canister and inhaling the drug, patients need to hold their breaths for at least 10 seconds or at least 4 seconds if the patient had breathing difficulties. This is for the purpose of depositing the drug particles in the bronchioles by providing sufficient time for it to remain in the airways. However, patients often forget or were unable to hold their breaths due to asthma relapse. 
Before video education, it was discovered that asthma patients who attempts to continue the second dose gave a lag-time of fewer than 10 seconds after the first dose. The time-lag needed before the second round of dosage is related to the redistribution of the drug in the inhaler device. sufficient time-lag is required for the drug-propellant to fill the metering chamber and for the spray to provide an optimal therapeutic effect (Zazuli et al., 2018).

Based on the results of a review of articles that observing the effect of pharmacist counseling and the use of electronic media on improving asthma management, it shows that regular counseling by pharmacists can increase knowledge of asthma from patients, interventions given to patients provide an increase in the ACQ score (Asthma Control Questionnaire). ACQ score shows improvement in asthma control such as: minimum symptoms at night, no activity limitations including exercise, minimum bronchodilator requirements, normal PEF (Peak Expiratory Flow) score. In addition, providing pharmacist education and counseling provides improved quality of life for patients and increased patient adherence to medication. This is also proved by the improvement of lung function and the rare exacerbation of asthma (Fadhilah \& Putriana, 2013).

\section{CONCLUSION}

Providing educational videos to asthma patients can increase patient's knowledge and understanding regarding the procedures for using Ventolin Inhaler. Errors made during the application of each step can influence the effectiveness of drug therapy and can lead to unwanted side effects. Further community service is suggested in the form of asthma patient compliance as seen in ACT (Asthma Control Test) of patients using Ventolin Inhalers where there is a link between the procedure completeness for inhaler device usage and the patient's asthma control.

\section{ACKNOWLEDGMENT}

A special thank-you to the Ma Chung University lecturer team, especially to the students who aided in the process of recording videos and collecting data on asthma patients at Probolinggo Hospital. Special thank-you is also given to the LPPM of Ma Chung University with the number: 046/MACHUNG/LPPM-MAG-IbM/III/2020 for helping us with the funding and ensure a smooth community service process. 


\section{REFERENCES}

Asthma, G. I. for. (2020). Global Strategy For Asthma Management And Prevention. Global Initiative for Asthma.

Fadhilah, N., \& Putriana, N. A. (2013). Review Artikel: Pengaruh Konseling Apoteker dan Pemanfaatan Media Elektronik Terhadap Perbaikan Manajemen Asma. Farmaka, 14(4), 1-15.

June, I. M., Kadu, P., Kendre, P., \& Gursal, K. (2016). Dry Powder Inhaler : A Review. Journal of Advanced Drug Delivery (JADD), 3(3), 42-52.

Kemenkes RI. (2012). Pedoman Pengendalian Penyakit Asma.

Lee, S. M., Chang, Y. S., Kim, C. W., Kim, T. B., Kim, S. H., Kwon, Y. E., Jee, Y. K. (2011). Skills in handling Turbuhaler, Diskus, and pressurized metered-dose inhaler in Korean asthmatic patients. Allergy, Asthma and Immunology Research, 3(1), 46-52. https://doi.org/10.4168/aair.2011.3.1.46

Lorensia, A., Queljoe, D. de, \& Valensia, Y. (2018). Karakteristik Informasi Terkait Cara Penggunaan Metered-Dose Inhaler dengan Spacer yang Mengandung Kombinasi Beta-2 Agonis dan Kortikosteroid oleh Apoteker di Apotek Wilayah Surabaya Timur. Jurnal Ilmiah Manuntung, 4(1), 15-27.

Lorensia, A., \& Suryadinata, R. V. (2018). Panduan Lengkap Penggunaan Macam-macam Alat Inhaler pada Gangguan Pernafasan. Surabaya: M-Brothers Indonesia.

Pratiwi, H., Nuryanti, N., Fera, V. V., Warsinah, W., \& Sholihat, N. K. (2016). Pengaruh Edukasi Terhadap Pengetahuan, Sikap, Dan Kemampuan Berkomunikasi Atas Informasi Obat. Kartika Jurnal Ilmiah Farmasi, 4(1), 10-15. https://doi.org/10.26874/kjif.v4i1.51

RI, K. K. (2018). Hasil Utama RISKESDAS.

Usmani, O. S. (2019). Choosing the right inhaler for your asthma or COPD patient. Therapeutics and Clinical Risk Management, (15), 461-472. Retrieved from http://dx.doi.org/10.2147/TCRM.S160365

Zazuli, Z., Ramasamy, K., \& Adnyana, I. K. (2018). Evaluating Inhaler Use Technique among Asthma and COPD Patients at a Primary Health Care Unit: A Pilot Study in Selangor Malaysia. JURNAL MANAJEMEN DAN PELAYANAN FARMASI (Journal of Management and Pharmacy Practice), 8(2), 80.

https://doi.org/10.22146/jmpf.33829

(C) 2021 by authors. Content on this article is licensed under a Creative Commons Attribution 4.0 International license. (http://creativecommons.org/licenses/by/4.0/). 
Original Title:

Analisis Kelengkapan Prosedur Penggunaan Ventolin Inhaler dengan Menggunakan Video pada Pasien Asma di RS Probolinggo

Abstrak. Asma merupakan penyakit paru kronis yang bersifat obstruktif sehingga menimbulkan gejala sesak napas di mana membutuhkan strategi diagnostik dan manajemen pengobatan yang berbeda. Penyakit tersebut membutuhkan pengobatan jangka panjang dan diharapkan pasien asma tetap dalam keadaan terkontrol. Masih banyaknya ditemukan kekambuhan pada pasien asma yang diakibatkan karena ketidaktepatan/ketidaklengkapan prosedur penggunaa alat inhaler. Tujuan dilakukan pengabdian ini untuk meningkatkan pengetahuan dan pemahaman tentang kelengkapan prosedur cara penggunaan Ventolin Inhaler dengan menggunakan video sehingga tercapainya efektivitas terapi yang diharapkan dan pasien asma dapat terkontrol/tidak kambuh asma-nya. Teknik pengumpulan data dilakukan secara observasi berupa checklist yang berisi prosedur penggunaan inhaler dan dianalisis secara deskriptif. Observasi dilakukan sebelum dan 1 bulan sesudah edukasi. Edukasi berupa video diberikan pada hari 1. Video berisi tentang prosedur penggunaan alat inhaler yang di upload di youtube. Selain itu, dapat diberikan juga melalui whatsapp pasien. Proses pengambilan data dilakukan dari bulan April hingga Juli 2020. Terdapat perbedaan jumlah pasien sebelum dan sesudah pemberian edukasi video. Hal ini menunjukkan adanya tingkat pengetahuan dan pemahaman pasien asma terkait kelengkapan prosedur penggunaan Ventolin Inhaler. Kesalahan dalam setiap step dapat berpengaruh pada efektivitas terapi obat dan dapat mengakibatkan timbulnya efek samping bila tidak menggunakan alat inhaler secara benar.

Kata kunci: inhaler, video, asma, teknik penggunaan, kuesioner 